TABLE I

Consultant vacancies psychiatry: 'British Medical Journal': September 1986-87

\begin{tabular}{|c|c|c|c|c|c|c|c|c|c|c|}
\hline & $\begin{array}{c}\text { General } \\
\text { Adult }\end{array}$ & $\begin{array}{c}\text { General } \\
\text { and } \\
\text { Interest }\end{array}$ & $\begin{array}{l}\text { Psycho- } \\
\text { geriatric }\end{array}$ & $\begin{array}{l}\text { General } \\
\text { and } \\
\text { Psycho- } \\
\text { geriatric }\end{array}$ & $\begin{array}{l}\text { Psycho- } \\
\text { therapy }\end{array}$ & Forensic & $\begin{array}{l}\text { Child and } \\
\text { Adolescent }\end{array}$ & Private & $\begin{array}{c}\text { Mental } \\
\text { Handicap }\end{array}$ & TOTAL \\
\hline \multicolumn{11}{|l|}{ England and Wales } \\
\hline Total & 56 & 38 & 43 & 16 & 10 & 10 & 43 & 4 & 25 & 245 \\
\hline Readvertised in the year & 12 & 9 & 7 & 3 & 1 & 5 & 4 & - & 1. & 42 \\
\hline Readvertised twice in & & & & & & & & & & \\
\hline the year & 2 & 4 & 1 & - & - & 1 & 1 & - & - & 9 \\
\hline Full-time academic & 2 & 1 & 2 & 0 & 0 & 1 & 1 & - & 1 & 8 \\
\hline Academic sessions & 3 & - & 2 & 一 & - & - & 3 & - & 1 & 9 \\
\hline \multicolumn{11}{|l|}{ Scotland } \\
\hline Total & 10 & 3 & 2 & 2 & - & - & 3 & - & 3 & 23 \\
\hline Northern Ireland & & & & & & & & & & · \\
\hline Total & 4 & - & 一 & - & - & - & 1 & 一 & 3 & 8 \\
\hline \multicolumn{11}{|l|}{ Other } \\
\hline Total & 1 & - & - & - & 1 & - & 2 & - & - & 4 \\
\hline
\end{tabular}

psychiatrists, four times the number of posts for psychotherapists or forensic psychiatrists and about twice the number for specialists in mental handicap.

At the present time there are no senior registrar posts offering the prospect of training to become a psychogeriatrician from the time of appointment: training is available within rotation schemes in general psychiatry with the option of one year of specialist training at maximum within a three to four year rotation, with two years devoted to general psychiatry and other specialist experiences offered as alternatives to 'old age' in the third or fourth year. It is most unlikely that appointment committees are selecting senior registrars with a balance of career aspirations that one in three will become a psychogeriatrician. It is most unlikely that training in the first two years of general psychiatry will be designed to encourage senior registrars to specialise in old age. We know that no more than half the senior registrars who chose to take the old age option from amongst the specialist experiences offered go on to become psychogeriatricians. ${ }^{1}$ If we are to use our senior registrar posts responsibly to equip people for the careers that are required by Health Districts something must be done to ensure that a greater proportion of trainees are prepared for work with the elderly.

It seems to me there are two main options: for old age psychiatry to become a subspecialty akin to child and adolescent psychiatry, forensic psychiatry, geriatric medicine etc, with designated senior registrar posts that guarantee a training for this work and with numbers tailored to predicted requirements, or general psychiatry adopts a more realistic view of its old age component and all senior registrars be required to receive one year of their training with an old age service, probably in their second or third year of training, with other specialist experiences remaining as additional options in the third or fourth year.

Withington Hospital

D. J. JOLLEY

West Didsbury, Manchester

REFERENCE

${ }^{1}$ Jolley, D. \& HoRton, R. (1986) Senior registrars posts in old age psychiatry. Bulletin of the Royal College of Psychiatrists, 10, 213-214.

\section{Psychiatric services in North Wales}

DeAR SIRS

The Psychogeriatric Department has been recognised as a separate service by the country as a whole for the last 20-25 years. However, a full-time specialist in Clwyd North was appointed only about a year ago. Perhaps this would be a good time to stop, reflect and do some 'stocktaking'.

There are two counties in North Wales, i.e. Clwyd and Gwynedd. The Department of Psychiatry of Old Age, which has emerged in the last year, covers Colwyn and Rhuddlan Districts with an elderly (over 65) population of 24,000 . However, as the adjoining county has no psychogeriatric cover at all, the team is in fact shouldering an old age population of 35,000 . The guidelines from the College ${ }^{1}$ 
and the norms from The Rising Tide ${ }^{2}$ recommend, for a comprehensive service, i.e. functional and organic, 35 (6) assessment beds, $100(26)$ rehabilitation and continuing care beds, and 150 (20 to come) day hospital places. (The figures in the brackets are the existing provisions.) There are no immediate plans to increase the number of beds in the next 10 years. It is clearly apparent that these present provisions fall far short of anybody's recommendation.

As a result of the shortage of statutory beds, the bulk of the elderly are looked after by the private sector. Whereas 900 elderly are looked after in private beds (probably half of these are mentally ill), only 38 beds are designated by statutory authorities (Health Authority 26, Social Services Department 12).

There is no formal screening by Medical and Social Service Departments before they are admitted to private beds and so elderly people with less severe mental illness are looked after by expensive methods when they are entitled to Supplementary Benefit. Of course, treatable illnesses might never be brought to light.

Having created this private sector bonanza, the Government are now changing the rules of the game. Firstly, it is suggested that the funding for the Supplementary Benefit should come from the local authorities. Secondly, it is trying to invalidate from the entitlement of Supplementary Benefit the homes run with either NHS Management or NHS Staff secondment. This might close the door for the private sector beds altogether.

Without beds and provision, how can a small team of workers cope with a swelling tide of elderly, other than drowning in frustration and disillusionment? Perhaps that was what was meant by the HAS when they named their Report The Rising Tide (Keep Away!).

R. Viswanathan

North Wales Hospital

K. Balasubramanian

Denbigh, Clwyd

\section{REFERENCES}

'Royal College of Psychiatrists (1981) Interim guidelines for regional advisers on consultant posts in psychiatry of old age. Bulletin of the Royal College of Psychiatrists, 5, 110-111.

${ }^{2}$ Health Advisory Service (1982) The Rising Tide (Developing Services for Mental Illness in Old Age). Sutton: NHS Health Advisory Service.

\section{Medical insurance fees}

DeAR SIRS

It would be of interest to know if the members of the Royal College of Psychiatrists share the official view of the College in relationship to the present situation.

On querying as to the College's attitude, the Executive and Finance Committee reported back that the increase in Defence Fees was an issue that concerned "terms and conditions of service" and therefore was not within the remit of the College.
I am sure that financially hard pressed junior psychiatrists would not share this view. It is of interest in a recent article in the British Medical Journal ${ }^{1}$ that a random analysis of 100 medico legal cases in the West Midlands did not contain one psychiatric case. Clearly, psychiatrists are being overcharged. It could be strongly argued that the College should be actively involved in supporting a differential for psychiatrists and also putting pressure on the Health Service to pay the insurance cover for psychiatrists in the Health Service.

R. LUCAS

Claybury Hospital

Woodford Green, Essex

REFERENCE

${ }^{1}$ Hawkins, C. \& Paterson, I. (1987) Medicolegal audit in the West Midlands region: analysis of 100 cases (1987) British Medical Journal, 295, 1533-1536.

\section{Assessment of drunk patients}

DeAr Sirs

The article 'Patients at a Psychiatric Walk-in ClinicWho, How, Why, and When' by Haw, Lanceley \& Vickers (Bulletin, October 1987, 11, 329-332) stimulated my interest. It provided a useful overview of the operation of the Maudsley Emergency Clinic and reminded me of my experience of working in a similar setting, the Assessment Centre of a large urban psychiatric hospital in Dublin. ${ }^{1}$ I was struck by the statement that "it is the clinic's policy not to interview drunk patients and so no details, other than their name and arrival time, were recorded". Alas, by this policy I fear a possible important therapeutic intervention is lost.

In Dublin the problems caused by 'drunk and drinking patients' attending the Assessment Centre were considerable and a major hassle for harassed registrars covering the centre at night-time. Policy at the centre, which had eight beds for lodging or 'guesting' patients overnight as indicated, was to refer all such patients to a nearby Alcoholism Treatment Unit for assessment at the next available clinic time. In the absence of guidelines individual doctors were left to decide their own approaches to the management of drunken patients presenting at night-time. A small research project helped clarify one approach.

Over a 10 week period specific information on every patient presenting to the centre with problems directly related to alcohol abuse was collected. Of 118 such patients, $85 \%$ were males with a mean age of 38.2 years (s.d. 10.7) and $15 \%$ were females with a mean age of 42.7 years (s.d. 10.9). Approximately one third were single, one third married, and the remainder separated; $62 \%$ were unemployed and $24 \%$ were of no fixed abode; $65 \%$ had one or more previous psychiatric admission; $59 \%$ reported drinking within the previous six hours and $52 \%$ were drunk on presentation, with a further $19 \%$ judged to be 'smelling 